\title{
Plasma concentrations of glucagon-like peptide 1 and 2 in calves fed calf starters containing lactose
}

\author{
Y. Inabu, ${ }^{*}$ A. Saegusa, $†$ K. Inouchi, $†$ S. Koike, $¥$ M. Oba, $§$ and T. Sugino*1 \\ *The Research Center for Animal Science, Graduate School of Biosphere Science, Hiroshima University, Higashi-Hiroshima, Japan 739-8528 \\ †Purchasing and Supplying Department, Dairy Technology Research Institute, The National Federation of Dairy Co-operative Associations \\ (ZEN-RAKU-REN), Nishi-shirakawa, Fukushima, Japan 969-0223 \\ ¥Department of Animal Science, Graduate School of Agriculture, Hokkaido University, Sapporo, Japan 060-8589 \\ $\S$ Department of Agricultural, Food and Nutritional Science, Faculty of Agricultural, Life and Environmental Sciences, University of Alberta, \\ Edmonton, Canada T6G 2P5
}

\begin{abstract}
The objective of this study was to evaluate the effects of lactose inclusion in calf starters on plasma glucagonlike peptide (GLP)-1 and GLP-2 concentrations and gastrointestinal tract development in calves. Holstein bull calves $(\mathrm{n}=45)$ were raised on an intensified nursing program using milk replacer containing $28.0 \% \mathrm{CP}$ and $15.0 \%$ fat, and were fed a texturized calf starter containing 0 (control), 5.0 (LAC5), or $10.0 \%$ (LAC10; $\mathrm{n}=15$ for each treatment) lactose on a DM basis. Lactose was included in the starter by partially replacing dry ground corn in pelleted portion of the starter. All calf starters were formulated with $23.1 \% \mathrm{CP}$. The ethanol-soluble carbohydrate concentrations of the control, LAC5, and LAC10 starters were 7.3, 12.3, and $16.8 \%$ on a DM basis, respectively. Starch concentrations of the control, LAC5, and LAC10 starters were 29.7, 27.0, and $21.4 \%$ on a DM basis, respectively. All calves were fed treatment calf starters ad libitum. Blood samples were obtained weekly from 1 to $11 \mathrm{wk}$ of age, and used to measure plasma GLP-1, GLP-2, and insulin concentrations, serum $\beta$-hydroxybutyrate (BHB) concentration, and blood glucose concentration. At $80 \mathrm{~d}$ of age, calves were euthanized, and weights of the reticulorumen, omasum, abomasum, small intestine, and large intestine tissue were measured. Serum BHB concentration was higher for calves fed the LAC10 $(171 \mu \mathrm{mol} / \mathrm{L})$ starter than for those fed the control $(151 \mu \mathrm{mol} / \mathrm{L})$ and LAC5 $(145 \mu \mathrm{mol} / \mathrm{L})$ starters. Plasma GLP-1 and GLP-2 concentrations did not differ between treatments. However, relative to the baseline (1 wk of age), the plasma GLP-1 concentration was higher for the LAC10 (125.9\%) than for the LAC5 (68.2\%) and control (36.8\%), and for the LAC5 than
\end{abstract}

Received March 22, 2017.

Accepted July 24, 2017.

${ }^{1}$ Corresponding author: sugino@hiroshima-u.ac.jp for the control (36.8\%). Moreover, similar differences between treatments were observed for GLP-2 concentration relative to the baseline $(88.2,76.9$, and $74.9 \%$ for LAC10, LAC5, and control treatments, respectively). The serum BHB concentration was positively correlated with the plasma GLP-1 concentration ( $\mathrm{r}=$ 0.428). Furthermore, the plasma GLP-1 concentration was positively correlated with the insulin concentration $(\mathrm{r}=0.793)$. The weights of the reticulorumen, omasum, abomasum, small intestine, and large intestine were not affected by the treatments. In conclusion, inclusion of lactose in calf starters resulted in higher plasma GLP-1 and GLP-2 concentrations, and BHB might be associated with higher plasma GLP-1 concentration.

Key words: lactose inclusion, gut-derived peptide, glucagon-like peptide 1 , glucagon-like peptide 2

\section{INTRODUCTION}

Gut-derived peptides, secreted in response to ingested nutrients, are known to play important roles in nutrient utilization and in the physical, morphologic, and metabolic transformation of growing animals. Among such peptides are the glucagon-like peptide (GLP)-1 and GLP-2; both are produced by enteroendocrine Lcells of the gastrointestinal tract (GIT), primarily from the distal intestine (Burrin et al., 2003). The L-cells produce GLP-1 and GLP-2 as part of a proglucagon gene $(G C G)$, which is larger precursor of GLP-1 and GLP-2 (Burrin et al., 2003). Glucagon-like peptide-1 plays a role in glucose homeostasis via the stimulation of insulin secretion in both nonruminants (O'Halloran et al., 1990; Holz et al., 1993) and ruminants (Faulkner, 1991; Edwards et al., 1997; Kurose et al., 1999) as well as through its own direct action (Luque et al., 2002; Acitores et al., 2005; Sancho et al., 2005, 2006). On the other hand, GLP-2 plays a role in stimulation of intestinal growth in nonruminants (Drucker et al., 1996; Kato et al., 1999; Hartmann et al., 2000). Moreover, Taylor- 
Edwards et al. (2011) reported that ruminants respond to GLP-2 in a manner similar to that of nonruminants.

Previous studies reported that VFA, especially butyrate, are main secretagogues for GLP-1 and GLP-2 in ruminants (Fukumori et al., 2012; Elsabagh et al., 2017), and Górka et al. (2009) reported that sodium butyrate supplementation in milk replacers and calf starters increased GLP-2 secretion in calves.

Several studies have shown that the feeding of lactose increases ruminal butyrate concentration in dairy cows (DeFrain et al., 2004; Oba et al., 2015; Gao and Oba, 2016). Fermentation products in the rumen, particularly butyrate, are considered the main stimulators of GIT development (Sander et al., 1959; Steele et al., 2016). In previous studies, sodium butyrate supplementation in calf starters increased reticulorumen weight relative to whole stomach weight and small intestine weight relative to BW in calves (Górka et al., 2011, 2014).

Based on this information, it was expected that lactose inclusion in the diet of calves would stimulate GIT development via stimulation of GLP-1 and GLP-2 secretion. Therefore, the objective of our study was to evaluate the effects of inclusion of lactose in calf starters on plasma GLP-1, GLP-2, and insulin concentrations, serum BHB and blood glucose concentrations, and GIT development in calves.

\section{MATERIALS AND METHODS}

\section{Animals and Diets}

The procedures used in the present study were performed in accordance with principles and guidelines for animal use set by Hiroshima University, and all experimental procedures were approved by the Animal Care and Use Committee of Hiroshima University. The detailed procedure was described in a companion paper (Saegusa et al., 2017). Forty-five Holstein bull calves, $\mathrm{BW}$ of $46.7 \pm 0.7 \mathrm{~kg}$ and $5.0 \pm 0.1 \mathrm{~d}$ of age (mean \pm SE), were born on March 20 to April 13, 2015 (n = $21)$ and May 7 to June 2, $2015(\mathrm{n}=24)$. Calves were further blocked by birthdate, BW, and farm origin, and randomly assigned to 1 of 3 calf starter treatments: fed texturized calf starter (control), and calf starter where starch was replaced with lactose at 5\% (LAC5) or 10\% (LAC10; $\mathrm{n}=15$ for each treatment) on a DM basis. Calves were fed calf starters from 1 wk of age, after the first blood sampling. Ingredient composition of calf starter formulations (\% of DM) is shown in Table 1, which is adapted from a companion paper of Saegusa et al. (2017). As shown in Table 1, lactose was included in the pelleted portion in the calf starter by partially replacing dry ground corn. All calf starters were isonitrogenous with actual CP concentrations in the control,
Table 1. Ingredient composition of calf starters (adapted from Saegusa et al., 2017)

\begin{tabular}{lrrr}
\hline & \multicolumn{3}{c}{ Treatment } \\
\cline { 2 - 4 } Composition & Control & LAC5 & LAC10 \\
\hline Ingredient, \% of DM & & & \\
Steam-flaked corn grain & 9.9 & 9.9 & 9.9 \\
Steam-flaked barley grain & 20.2 & 20.2 & 20.2 \\
Alfalfa dehydrated pellet & 3.7 & 3.7 & 3.7 \\
Molasses cane & 0.4 & 0.4 & 0.4 \\
Pellet & 65.8 & 65.8 & 65.8 \\
In pellet, \% of DM & 14.9 & 8.2 & 1.6 \\
Dry ground corn & 1.6 & 1.6 & 1.6 \\
Wheat feed flour & 2.2 & 3.4 & 4.4 \\
Soybean flour & 9.0 & 9.0 & 9.0 \\
Wheat bran & 17.3 & 16.8 & 14.6 \\
Soybean meal & 1.3 & 1.3 & 1.3 \\
Rapeseed meal & 7.1 & 7.1 & 7.1 \\
Heated soybean & 2.3 & 2.6 & 4.1 \\
Corn gluten meal & 4.1 & 4.1 & 4.1 \\
Ground beet pulp & 0.0 & 0.6 & 1.9 \\
Dehydrated alfalfa & 3.3 & 3.3 & 3.3 \\
Cane molasses & 1.2 & 1.2 & 1.2 \\
Calcium carbonate & 0.7 & 0.7 & 0.7 \\
Salt & 0.6 & 0.6 & 0.6 \\
Calcium phosphate & 0.5 & 0.5 & 0.5 \\
GC mix 21 & 0.0 & 5.0 & 10.0 \\
Lactose & & & \\
\hline
\end{tabular}

${ }^{1}$ Heated soybean (SoyPlus, West Central Cooperative, Ames, IA).

${ }^{2} \mathrm{GC}$ mix 21 (trace minerals and vitamins premix, Zenrakuren, Tokyo, Japan), containing $16.0 \%$ vitamin mix, $6.3 \%$ trace mineral mix, and $77.7 \%$ rice bran.

${ }^{3}$ Lactose (Hilmar 5030 Extra Fine Grind Lactose, Hilmar Ingredients, Hilmar, CA).

LAC5, and LAC10 starters of $24.0 \pm 0.4,23.3 \pm 1.0$, and $24.4 \pm 0.8 \%$ (mean $\pm \mathrm{SD}$ ) on a DM basis, respectively. Ethanol-soluble carbohydrate concentrations in the control, LAC5, and LAC10 starters were $10.3 \pm 0.6$, $11.7 \pm 0.7$, and $15.8 \pm 0.7 \%$ on a DM basis, respectively. Starch concentrations of the control, LAC5, and LAC10 starters were $29.7 \pm 1.1,27.0 \pm 2.3$, and $21.4 \pm$ $1.1 \%$ on a DM basis, respectively. The NDF concentrations in control, LAC5, and LAC10 were $16.5 \pm 0.9$, $16.6 \pm 0.6$, and $17.6 \pm 0.5$ on a DM basis, respectively. Calves had free access to water throughout the study.

Calves were raised on an intensified nursing program using a commercial milk replacer containing $28 \%$ CP and $15 \%$ fat at $200 \mathrm{~g} / \mathrm{L}$. The milk replacer was fed in 2 equal portions at 0630 and $1630 \mathrm{~h}$. After arrival, the amount of milk replacer fed to calves was gradually increased from 600 to $1,200 \mathrm{~g} / \mathrm{d}$ over a 7 -d period to adapt calves to intensive liquid feeding. Calves were fed milk replacer at $1,200 \mathrm{~g} / \mathrm{d}$ from 3 to $5 \mathrm{wk}$ of age, and were weaned at 6 wk of age by reducing the provided milk replacer to $800 \mathrm{~g} / \mathrm{d}$. The amount of milk replacer offered was further reduced to $600 \mathrm{~g} / \mathrm{d}$ at wk 7 , and no milk was provided at wk 9. Calves were offered one of the treatment calf starters ad libitum at $1000 \mathrm{~h}$ ini- 
tially, but when calves consumed more than $900 \mathrm{~g} / \mathrm{d}$ (as fed) of starter, calves were fed twice daily (1000 and $1500 \mathrm{~h}$; equal volume of starter). Calves were fed $200 \mathrm{~g} / \mathrm{d}$ of calf starters initially, but when the amount of refusals was below $100 \mathrm{~g}$, the amount of calf starters provided increased by 300 g. Furthermore, calves were offered chopped kleingrass hay at $50 \mathrm{~g} / \mathrm{d}$ from 6 to 7 wk of age, $100 \mathrm{~g} / \mathrm{d}$ from 8 to 9 wk of age, and $150 \mathrm{~g} / \mathrm{d}$ after 10 wk of age.

Individual feed intakes were recorded daily, and BW was recorded weekly. Blood was sampled weekly before feeding milk replacer $(0600 \mathrm{~h})$ starting from 1 wk of age; this was achieved by using Vacutainers for the collection of plasma (Venoject II VP-H100K with heparin sodium, Terumo Corporation, Tokyo, Japan), serum (Insepack II SMD108CG with procoagulant and separating medium; Sekisui Medical, Tokyo, Japan), and whole blood (Venoject II VP-FH052K with sodium fluoride, heparin sodium, and EDTA-2Na, Terumo Corporation). Immediately after sample collection, aprotinin (500 kallikrein inhibitor units/mL of blood; Sigma-Aldrich Inc., Tokyo, Japan) was added to blood samples for plasma preparation. Blood samples were centrifuged at $1,800 \times g$ at $4^{\circ} \mathrm{C}$ for $20 \mathrm{~min}$, and both plasma and serum were collected. Plasma and serum samples were stored at -80 and $-20^{\circ} \mathrm{C}$, respectively, until analysis. Whole blood samples were stored at $4^{\circ} \mathrm{C}$ until analysis.

At $80 \mathrm{~d}$ old, calves were killed at $1300 \mathrm{~h}$ to collect digestive tract samples, and 3 stomach parts (reticulorumen, omasum, and abomasum), the small intestine, and the large intestine were separated, emptied, rinsed repeatedly with water, drained, and weighed individually.

\section{Sample Analysis}

Plasma, serum, and whole blood samples were analyzed for hormone, BHB, and glucose concentrations, respectively, and hormone concentrations in plasma were measured using a time-resolved fluoroimmunoassay. The plasma GLP-1 concentration was measured using a solid-phase competition immunoassay with europium (Eu)-labeled human GLP-1 and polystyrene microtiter strips (Nalgene Nunc Int., Tokyo, Japan) coated with anti-rabbit $\gamma$-globulin (Fukumori et al., 2012). Intra- and interassay coefficients of variation were 1.7 and $4.8 \%$, respectively, and the least detectable level was $0.024 \mathrm{ng} / \mathrm{mL}$. The plasma GLP-2 concentration was measured using a solid-phase competition immunoassay with Eu-labeled human GLP-2 (Peptide Institute Inc., Osaka, Japan), polyclonal anti-rat GLP-2 (Yanaihara Institute Inc., Shizuoka, Japan), and polystyrene microtiter strips coated with goat-anti-rabbit $\gamma$-globulin (Elsabagh et al., 2017). Intra- and interassay coefficients of variation were 2.7 and $2.2 \%$, respectively, and the least detectable level was $0.042 \mathrm{ng} / \mathrm{mL}$. The plasma concentration of insulin was measured using a solid-phase competition immunoassay with Eu-labeled bovine insulin and polystyrene microtiter strips coated with anti-guinea pig $\gamma$-globulin (Takahashi et al., 2006). Intra- and interassay coefficients of variation were 2.2 and $1.8 \%$, respectively, and the least detectable level was $0.016 \mathrm{ng} / \mathrm{mL}$. The serum BHB concentration was determined by enzymatic analysis using a clinical chemistry analyzer (Bio Majesty, JACK-BM, Jeol Ltd., Akishima, Tokyo, Japan), and the blood glucose concentration was also determined by enzymatic analysis with a clinical chemistry analyzer (Bio Majesty, JCABM9130, Jeol Ltd.). The serum IgG concentration was measured at $1 \mathrm{wk}$ of age via the single radial immunodiffusion method using a commercial kit (Bovine IgG SRID assay kit LL-70002, Life Laboratory, Yamagata, Japan). The serum IgG concentration for control, LAC5, and LAC10 were $7.60 \pm 1.01,6.46 \pm 1.05$, and $7.76 \pm 1.05 \mathrm{mg} / \mathrm{mL}$, respectively, and a positive correlation was observed between serum IgG and plasma GLP-1 concentrations $(\mathrm{r}=0.31, P=0.04$; Figure 1$)$. The value of the IgG concentration was included in the statistical model as a covariate.

\section{Statistical Analyses}

Repeated-measure ANOVA tests were performed to determine plasma hormone, serum BHB, and blood

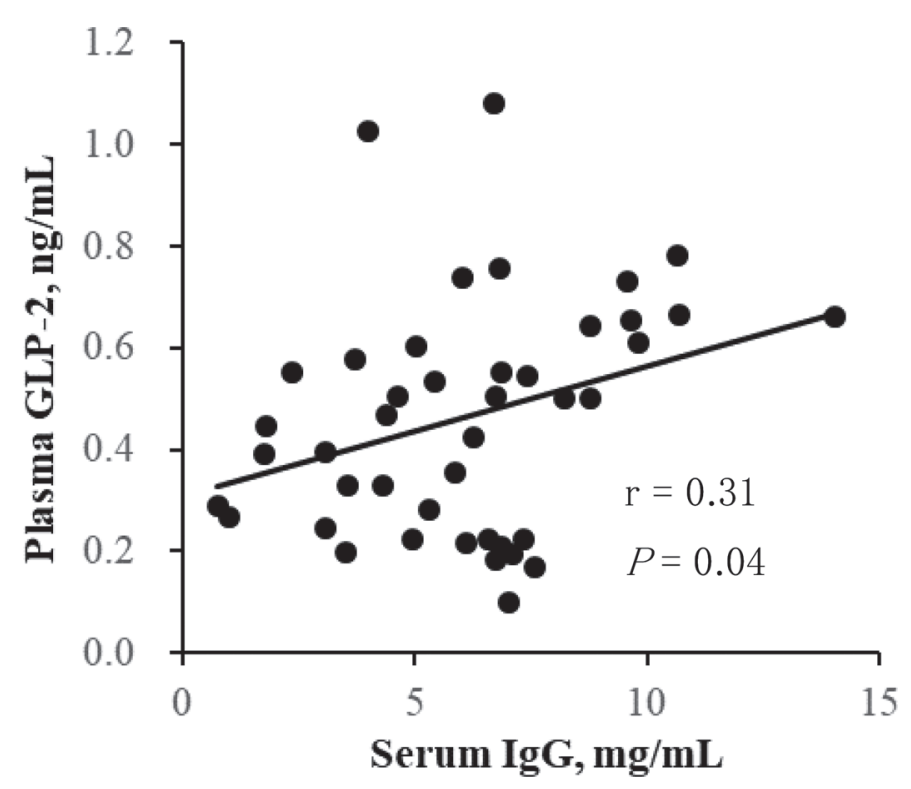

Figure 1. Correlation coefficient (r) between plasma glucagon-like peptide (GLP)-2 and serum IgG concentrations $(\mathrm{n}=43)$. 
glucose concentrations and the relative values of plasma hormone concentrations compared with that of the baseline (1 wk of age) using the PROC MIXED procedure in SAS (SAS Institute Inc., Cary, NC). Because calves were purchased at 2 different time points, the purchase time point effect and purchase time point by treatment interaction were included in the statistical model to account for possible confounding effects of the different environments to which the calves were exposed. Data were analyzed according to the following model:

$\mathrm{Y}_{\mathrm{ijk}}=\mu+\mathrm{T}_{\mathrm{i}}+\mathrm{W}_{\mathrm{j}}+\mathrm{P}_{\mathrm{k}}+\mathrm{TW}_{\mathrm{ij}}+\mathrm{TP}_{\mathrm{ik}}+\mathrm{Cov}+\mathrm{e}_{\mathrm{ijk}}$,

where $Y_{i j k}$ is the dependent variable, $\mu$ is the overall mean, $T_{i}$ is the fixed effect of treatment, $W_{j}$ is the fixed effect of the week used as a repeated measure, $\mathrm{P}_{\mathrm{k}}$ is the fixed effect of purchase time point, $\mathrm{TW}_{\mathrm{ij}}$ is the effect of treatment by week interaction, $\mathrm{TP}_{\mathrm{ik}}$ is the effect of treatment by purchase time point interaction, Cov is the IgG concentration of serum samples collected on wk 1 used as covariate, and $\mathrm{e}_{\mathrm{ijk}}$ is the error term. Treatment effects were declared significant at $P<0.05$.

The parameters of the GIT development were analyzed using the following model:

$$
\mathrm{Y}_{\mathrm{ij}}=\mu+\mathrm{T}_{\mathrm{i}}+\mathrm{P}_{\mathrm{j}}+\mathrm{TP}_{\mathrm{ij}}+\mathrm{Cov}+\mathrm{e}_{\mathrm{ij}},
$$

where $Y_{i j}$ is the dependent variable, $\mu$ is the overall mean, $T_{i}$ is the fixed effect of treatment, $P_{j}$ is the fixed effect of purchase time point, $\mathrm{TP}_{\mathrm{ij}}$ is the effect of treatment by purchased time point interaction, $\mathrm{Cov}$ is the IgG concentration of serum samples collected on wk 1 used as covariate, and $\mathrm{e}_{\mathrm{ij}}$ is the error term.

Correlation coefficients ( $\mathrm{r}$ ) were determined between starter and hay intake as well as between plasma hormone and metabolite concentrations using Pearson correlation method in SAS (ver. 9.4, SAS Institute Inc., Cary, NC). One calf in the LAC5 treatment group had severe pneumonia and another calf in the LAC10 treatment group had severe arthritis; these calves were excluded from the statistical analysis.

\section{RESULTS AND DISCUSSION}

\section{GLP-1}

A time effect was observed for the GLP-1 concentration $(P<0.01$; Table 2$)$, and regardless of dietary treatments, the plasma GLP-1 concentration decreased from 1 to 6 wk of age and gradually increased thereafter (Figure 2A). A treatment by time interaction $(P$ $=0.01$ ) was also observed; however, this was mainly a result of differences between treatments at the initia- tion of the study. In addition, the plasma GLP-1 concentration was positively correlated with starter and hay intake $(\mathrm{r}=0.597, P<0.01$ and $\mathrm{r}=0.760, P<$ 0.01 , respectively; Table 3). Previous studies reported that dietary intake of fiber and short-chain fatty acids increased intestinal proglucagon expression in rodents (Reimer and McBurney, 1996; Reimer et al., 1997; Tappenden and McBurney, 1998; Nian et al., 2002). In the present study, we found that low serum BHB concentration was maintained before weaning, but increased after weaning (Figure 3A and Table 2; time $P<0.01)$. The serum BHB concentration positively correlated with starter and hay intake and the plasma GLP-1 concentration $(\mathrm{r}=0.979, P<0.01 ; \mathrm{r}=0.879, P$ $<0.01 ; \mathrm{r}=0.428, P=0.01$, respectively; Table 3$)$. The $\mathrm{BHB}$ is a measure of rumen epithelial metabolic activity, and it indicates the conversion of ruminal butyrate to serum BHB as it passes the rumen wall (Lane et al., 2000). Furthermore, the fermentation of calf starters increased ruminal concentrations of VFA, specifically of propionate and butyrate (Warner et al., 1956; Stobo et al., 1966). Therefore, in the present study, the increased serum BHB concentration depended on the ruminal fermentation of calf starters. The results of our previous study (sheep model) indicated that ruminal butyrate infusion increased plasma GLP-1 concentration (Elsabagh et al., 2017). Thus, GLP-1 secretion might be stimulated by increased ruminal butyrate production that is attributed to the fermentation of the calf starter or the serum BHB concentration, which results from increased ruminal butyrate in calves.

The presence of nutrients in the intestinal lumen stimulates the expression of $G C G$ mRNA in both nonruminants (Cordier-Bussat et al., 1998; Shin et al., 2005; Zhou et al., 2006) and ruminants (Taylor-Edwards et al., 2010). In nonruminants, glucose increases circulating glucagon-like peptides (Unger et al., 1968; Takahashi et al., 1990; Elliott et al., 1993). Regardless of dietary treatments, the blood glucose concentration, indicated by the amount of milk replacer provisioned, increased drastically from 2 to 4 wh of age, but decreased thereafter (Figure 3B and Table 2; time $P<$ 0.01). Furthermore, blood glucose concentration was negatively correlated with the plasma GLP-1 concentration $(\mathrm{r}=-0.553, P<0.01$; Table 3$)$. In nonruminants, glucose absorption from the gut enhances the secretion of glucagon-like peptides from L-cells (Unger et al., 1968; Holst et al., 1976; Ritzel et al., 1997). However, abomasal infusion of starch does not affect the plasma GLP-1 concentration in ruminants (Relling and Reynolds, 2008), which suggests that, unlike in nonruminants, in ruminants glucagon-like peptide secretion might not be very responsive to glucose. Alternatively, glucose may suppress GLP-1 secretion as in this study 

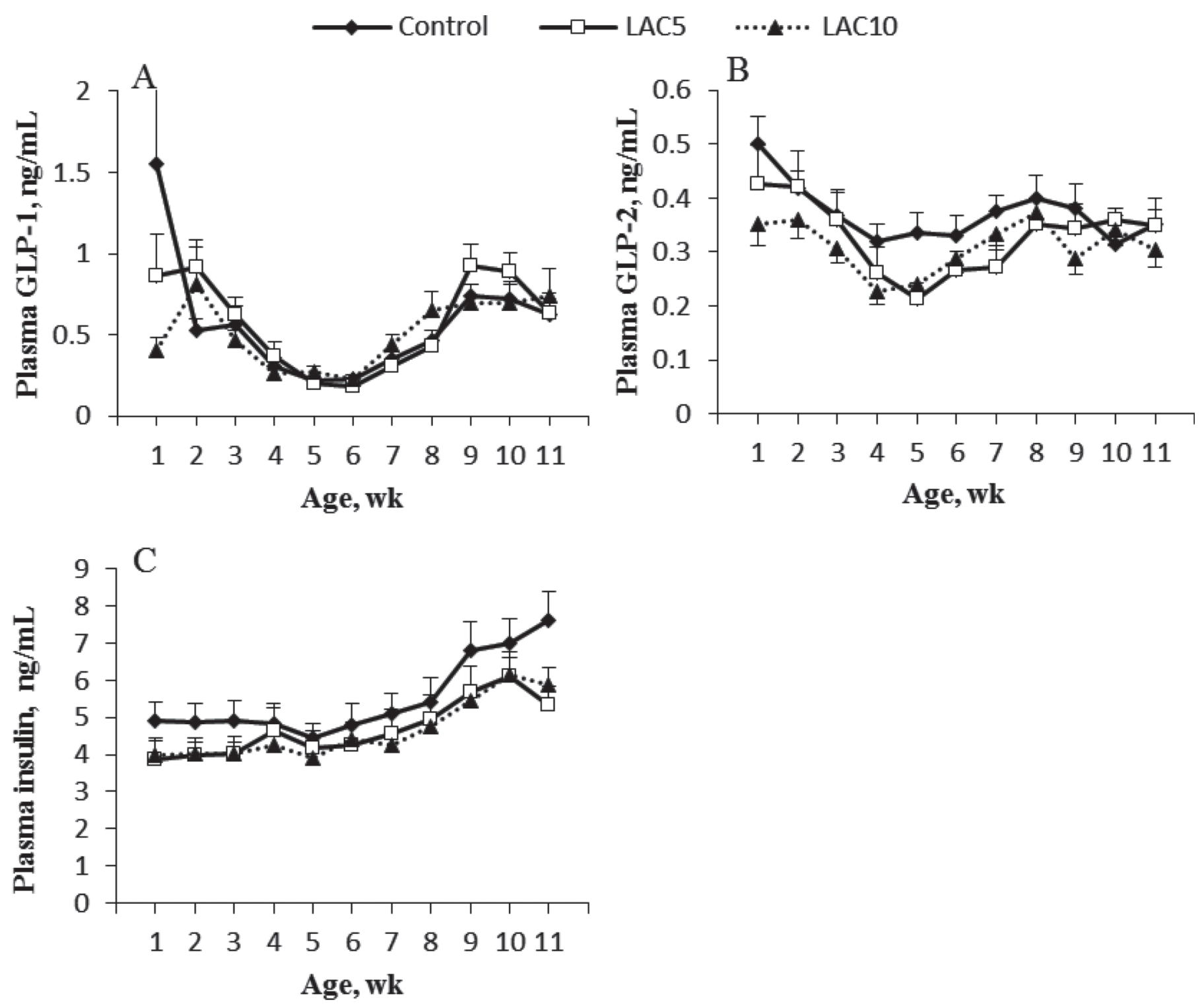

Figure 2. Plasma concentrations of glucagon-like peptide (GLP)-1 (A), GLP-2 (B), and insulin (C; ng/mL) for calves fed calf starters containing 0 (control), 5.0 (LAC5), or 10.0\% (LAC10) lactose on a DM basis. Results are expressed as LSM \pm SEM.

Table 2. Plasma hormone, serum BHB, and blood glucose concentrations for calves fed starters containing lactose at 0 (control), 5.0 (LAC5), or $10.0 \%$ (LAC10) on a DM basis

\begin{tabular}{|c|c|c|c|c|c|c|c|}
\hline \multirow[b]{2}{*}{ Item $^{1}$} & \multicolumn{3}{|c|}{ Treatment } & \multirow[b]{2}{*}{ SEM } & \multicolumn{3}{|c|}{$P$-value for fixed effect ${ }^{2}$} \\
\hline & Control & LAC5 & LAC10 & & $\mathrm{T}$ & Time & $\mathrm{T} \times$ time \\
\hline GLP-1, ng/mL & 0.57 & 0.59 & 0.51 & 0.05 & 0.51 & $<0.01$ & 0.01 \\
\hline GLP-2, ng/mL & $0.38^{\mathrm{a}}$ & $0.33^{\mathrm{b}}$ & $0.31^{\mathrm{b}}$ & 0.01 & $<0.01$ & $<0.01$ & 0.81 \\
\hline Insulin, ng/mL & $5.62^{\mathrm{a}}$ & $4.63^{\mathrm{b}}$ & $4.67^{\mathrm{b}}$ & 0.14 & $<0.01$ & $<0.01$ & 0.99 \\
\hline $\mathrm{BHB}, \mu \mathrm{mol} / \mathrm{L}$ & $151^{\mathrm{b}}$ & $144^{\mathrm{b}}$ & $172^{\mathrm{a}}$ & 5.6 & $<0.01$ & $<0.01$ & 0.30 \\
\hline Glucose, $\mathrm{mg} / \mathrm{dL}$ & 96.6 & 95.6 & 96.4 & 0.76 & 0.58 & $<0.01$ & 0.77 \\
\hline
\end{tabular}

$\overline{\mathrm{a}, \mathrm{b}}$ Main effects within a row with different superscripts differ $(P<0.05)$.

${ }^{1} \mathrm{LSM}$ of concentration from 1 to $11 \mathrm{wk}$ of age. GLP $=$ glucagon-like peptide.

${ }^{2} \mathrm{~T}=$ treatment; time $=$ weeks of age. 
Table 3. Correlation coefficient (r) between plasma hormone, serum BHB, and blood glucose concentrations and feed intake

\begin{tabular}{|c|c|c|c|c|c|c|c|}
\hline Item & Serum BHB & Blood glucose & Plasma GLP-1 & Plasma GLP-2 & Plasma insulin & Starter intake & Hay intake \\
\hline Serum BHB, $\mu \mathrm{mol} / \mathrm{L}$ & 1 & & & & & & \\
\hline Blood glucose, $\mathrm{mg} / \mathrm{dL}$ & $-0.417^{*}$ & 1 & & & & & \\
\hline Plasma GLP- $1,{ }^{1} \mathrm{ng} / \mathrm{mL}$ & $0.428^{*}$ & $-0.553^{*}$ & 1 & & & & \\
\hline Plasma insulin, $\mathrm{ng} / \mathrm{mL}$ & 0.159 & $-0.583^{*}$ & $0.793^{*}$ & $0.591 *$ & 1 & & \\
\hline Starter intake, $\mathrm{g} / \mathrm{d}$ & $0.979^{*}$ & $-0.385^{*}$ & $0.597^{*}$ & 0.178 & 0.175 & 1 & \\
\hline Hay intake, $\mathrm{g} / \mathrm{d}$ & $0.879^{*}$ & -0.423 & $0.760^{*}$ & 0.255 & $0.706^{*}$ & $0.901^{*}$ & 1 \\
\hline
\end{tabular}

${ }^{1} \mathrm{GLP}=$ glucagon-like peptide.

$* P<0.05$.

GLP-1 concentration decreased with calves' age and was negatively correlated with plasma glucose.

Contrary to our hypothesis, the plasma GLP-1 concentration was not affected by the lactose inclusion in calf starters (Table 2). At 1 wk of age, the GLP-1 concentration varied widely from 0.07 to $7.35 \mathrm{ng} / \mathrm{mL}$ and differed substantially among animals. Furthermore, an interaction was observed between treatment and time in plasma GLP-1 concentration, as a result of higher GLP-1 concentration in the control $(1.54 \pm 1.56 \mathrm{ng} /$ $\mathrm{mL} ; \mathrm{LSM} \pm \mathrm{SE})$ than in the LAC10 $(0.39 \pm 0.40 \mathrm{ng} /$ $\mathrm{mL})$ at $1 \mathrm{wk}$ of age $(P=0.01$; Table 2$)$. This aspect was likely attributed to individual variation rather than treatment, and a similar tendency was observed for plasma GLP-2 concentration of calves in previous study (Górka et al., 2009, 2011; Castro et al., 2016). However, relative to the baseline (1 wk of age; Figure 4A), the plasma GLP-1 concentration was higher $(P<0.01)$ for the LAC10 $(126.8 \pm 6.34 \%)$ than for the LAC5 $(68.5$ $\pm 6.35 \%)$ and for the control $(36.3 \pm 6.06 \%)$, and for the LAC5 than for the control. In the present study, no difference was observed in starter and hay intake across the 3 treatment groups (Saegusa et al., 2017), indicating that higher relative values of GLP-1 concentration observed for LAC5 and LAC10 are likely attributed to lactose inclusion in calf starters. However, as we did not measure nutrient composition of orts, we cannot exclude a possibility that pellet containing lactose was sorted, and it should be noted that extent of sorting could affect results of the present study.

As described above, ruminal butyrate or plasma BHB can stimulate GLP-1 secretion (Elsabagh et al., 2017). However, in the present study, the ruminal butyrate concentration did not differ across treatments at $80 \mathrm{~d}$ of age. This is contrary to Oba et al. (2015) who reported that ruminal dose of lactose increased ruminal molar proportion of butyrate in nonlactating nonpregnant dairy cows. Lack of treatment effect on ruminal butyrate concentration in our study might be partially attributed to fast absorption of butyrate at low rumi-

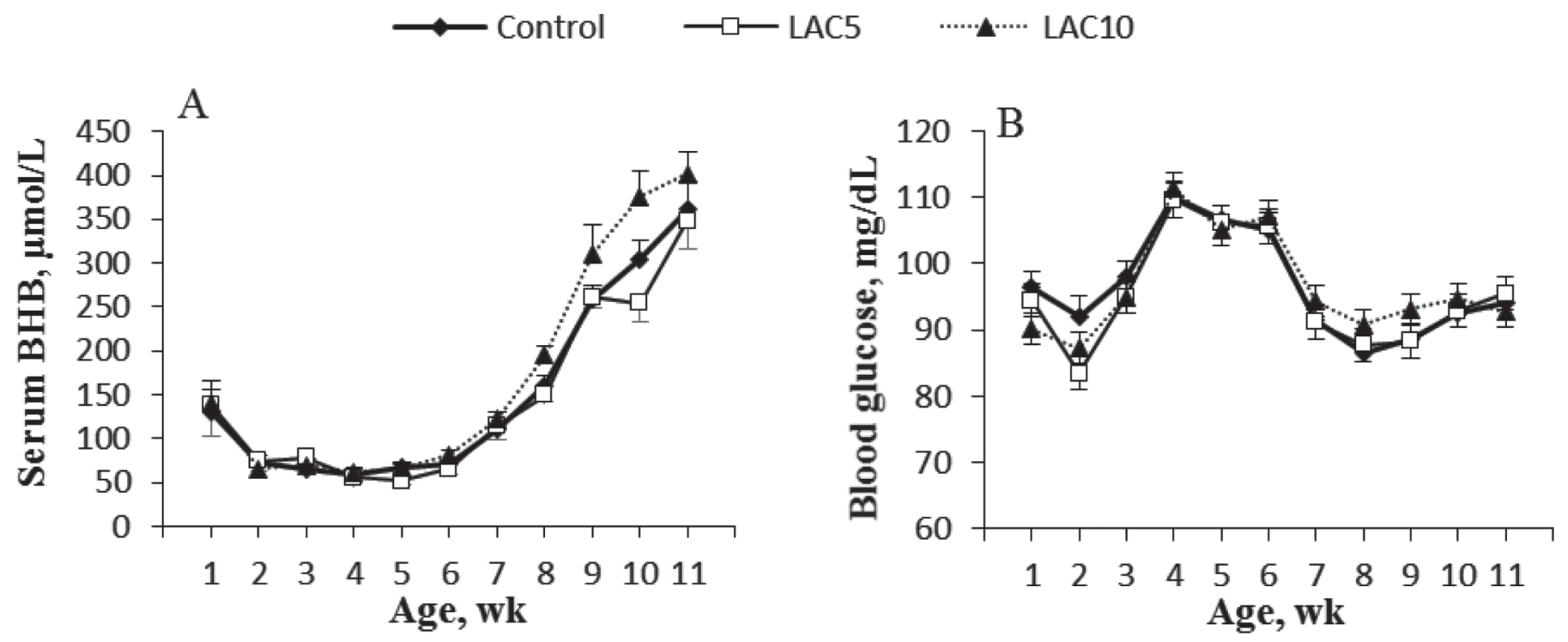

Figure 3. Serum BHB ( $\mu \mathrm{mol} / \mathrm{L} ; \mathrm{A})$ and blood glucose $(\mathrm{mg} / \mathrm{dL} ; \mathrm{B})$ concentrations for calves fed calf starters containing 0 (control), 5.0 (LAC5), or 10.0\% (LAC10) lactose on a DM basis. Results are expressed as LSM \pm SEM. 
nal $\mathrm{pH}$ after the fermentation of sugar (Saegusa et al., 2017). The serum concentration of BHB, which is a metabolite from ruminal butyrate, was higher $(P<$ 0.01; Table 2) for the LAC10 $(172 \pm 5.6 \mu \mathrm{mol} / \mathrm{L})$ than for the control $(151 \pm 5.4 \mu \mathrm{mol} / \mathrm{L})$, consistent with DeFrain et al. (2004) who reported that lactose feeding increased plasma BHB concentration in lactating dairy cows. As such, we cannot exclude a possibility that ruminal butyrate production increased without affecting its concentration in the rumen in our study. Therefore, in the present study, lactose inclusion in calf starters might enhance GLP-1 secretion via an increase in serum BHB concentration that might be associated with possible increase in ruminal butyrate production

The plasma insulin concentration was higher $(P<$ 0.01 ; Table 2) for the control $(5.62 \pm 0.14 \mathrm{ng} / \mathrm{mL})$ than for the LAC5 $(4.63 \pm 0.15 \mathrm{ng} / \mathrm{mL})$ and LAC10 (4.67 \pm
$0.14 \mathrm{ng} / \mathrm{mL}$ ). At 1 wk of age, the insulin concentration varied widely from 1.43 to $13.8 \mathrm{ng} / \mathrm{mL}$ and differed substantially among animals. Further, plasma insulin concentration was numerically higher for the control $(4.98 \pm 0.85 \mathrm{ng} / \mathrm{mL})$ at $1 \mathrm{wk}$ of age compared with that for the LAC5 $(3.83 \pm 0.86 \mathrm{ng} / \mathrm{mL})$ and LAC10 (4.02 \pm $0.86 \mathrm{ng} / \mathrm{mL}$ ), and a significant correlation was observed between plasma insulin concentration at 1 wk of age and at subsequent weeks $(\mathrm{r}=0.826, P<0.01)$. Therefore, higher concentrations of insulin in the control treatments might have resulted from individual variability rather than lactose inclusion. Furthermore, relative to the baseline, the plasma insulin concentration did not differ across the 3 treatment groups (Figure 4C). Thus, the plasma insulin concentration may not be affected by lactose inclusion in calf starters. A time effect was observed for the insulin concentration $(P<0.01$; Table
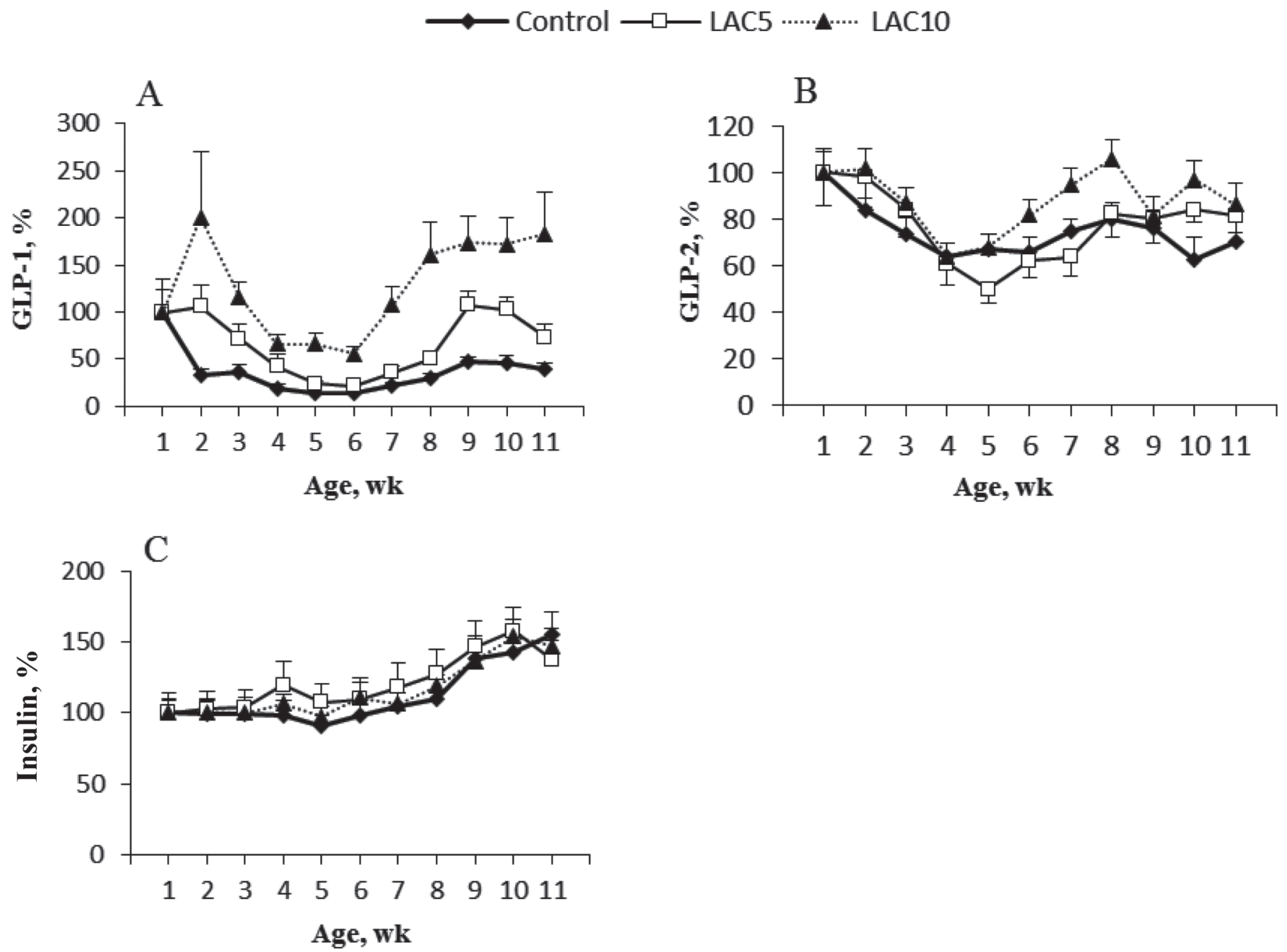

Figure 4. Relative values (\%) of plasma glucagon-like peptide (GLP)-1 (A), GLP-2 (B), and insulin (C) concentrations compared with those of the baseline (1 wk of age) for calves fed calf starters containing 0 (control), 5.0 (LAC5), or 10.0\% (LAC10) lactose on a DM basis. Results are expressed as LSM \pm SEM. 
2), and regardless of dietary treatments, plasma insulin concentration was low before weaning and increased as weaning approached (Figure 2C), consistent with previous reports (Klotz and Heitmann, 2007; Fukumori et al., 2012). The plasma concentration of insulin was positively correlated with that of GLP-1 $(\mathrm{r}=0.793$, $P<0.05$; Table 3). Fukumori et al. (2012) reported that the insulinotropic action of GLP-1 was only observed during the postweaning period in calves, but not during the preweaning period. In addition, circulating VFA concentrations increase after weaning (Klotz and Heitmann, 2006) because of increased ruminal fermentation. In the present study, plasma insulin concentration increased as weaning approached, and a similar fluctuation was observed for the GLP-1 concentration. Therefore, the insulinotropic actions of GLP-1 might be affected by the extent of rumen development.

\section{GLP-2}

A time effect was observed for the GLP-2 concentration $(P<0.01$; Table 2$)$, and regardless of dietary treatments, the fluctuation of the plasma GLP-2 concentration was similar to that of the GLP-1 concentration (Figure 2B). Both GLP-1 and GLP-2 are co-secreted from the intestinal L-cells (Burrin et al., 2003), and studies in nonruminants indicated that both GLP-1 and GLP-2 are secreted from L-cells in response to nutritional, hormonal, and neural stimulation (Burrin et al., 2003). Furthermore, our previous study suggested that GLP-1 and GLP-2 may be secreted simultaneously in sheep (Elsabagh et al., 2017). In the present study, the GLP-2 concentration was positively correlated with the GLP-1 concentration $(\mathrm{r}=0.700, P<0.01$; Table 3). Thus, GLP-1 and GLP-2 might be co-secreted in calves. Plasma GLP-2 concentration was negatively correlated with the blood glucose concentration $(\mathrm{r}=$ $-0.596, P<0.01$; Table 3). Elsabagh et al. (2017) reported that the GLP-2 secretion might not be promoted by circulating glucose levels, and the abomasal infusion of starch hydrolysate tends to decrease the expression of $G C G$ mRNA in the duodenum of growing beef steers (Taylor-Edwards et al., 2010). Therefore, our results are consistent with the results of these studies.

The plasma GLP-2 concentration was higher $(P<$ $0.01)$ for the control $(0.38 \pm 0.01 \mathrm{ng} / \mathrm{mL})$ than for the LAC5 $(0.33 \pm 0.01 \mathrm{ng} / \mathrm{mL})$ and LAC10 $(0.31 \pm$ $0.01 \mathrm{ng} / \mathrm{mL}$ ). At $1 \mathrm{wk}$ of age, the GLP-2 concentration varied widely from 0.05 to $1.08 \mathrm{ng} / \mathrm{mL}$ and differed substantially among animals. Furthermore, the plasma GLP-2 concentration was numerically higher for the control $(0.50 \pm 0.08 \mathrm{ng} / \mathrm{mL})$ at 1 wk of age compared with the LAC5 $(0.43 \pm 0.08 \mathrm{ng} / \mathrm{mL})$ and LAC10 (0.35 $\pm 0.08 \mathrm{ng} / \mathrm{mL}$ ) and a significant correlation was ob- served between the plasma GLP-2 concentration at 1 wk of age and at subsequent weeks $(\mathrm{r}=0.535, P<$ 0.01 ). Therefore, the higher concentration of GLP-2 in the control treatments might have resulted from individual variability rather than from lactose inclusion, and a similar tendency was observed for the plasma GLP-2 concentration of calves in previous study (Górka et al., 2009, 2011; Castro et al., 2016). Furthermore, relative to the baseline (1 wk of age; Figure 4B), the plasma GLP-2 concentration was higher $(P<0.01)$ for the LAC10 $(88.4 \pm 2.80 \%)$ than for the control $(75.4$ $\pm 2.70 \%)$ and LAC5 $(76.6 \pm 2.83 \%)$. Thus, the results indicated that lactose inclusion in calf starters might affect GLP-2 secretion. As previously mentioned, the feeding of lactose led to increased ruminal butyrate and plasma BHB concentration (DeFrain et al., 2004; Oba et al., 2015), and Górka et al. (2009) reported that sodium butyrate supplementation in milk replacers and calf starters enhanced GLP-2 secretion in calves. In our previous study, plasma GLP-2 concentration increased in response to the ruminal infusion of butyrate (Elsabagh et al., 2017). Furthermore, as mentioned previously, no difference was observed in starter and hay intake across 3 treatment groups in the present study (Saegusa et al., 2017). Therefore, the results of the present study suggest that lactose inclusion in calf starters might enhance GLP-2 secretion via increased ruminal butyrate production. Although plasma GLP-2 and GLP-1 concentrations were positively correlated and plasma GLP-1 concentration was positively correlated with starter and hay intake as well as with serum BHB concentration, the GLP-2 concentration was not correlated with starter and hay intake and serum BHB concentration, thus indicating that GLP-1 and GLP-2 secretion might not act in parallel in ruminants, despite the fact that they are secreted from the same cell.

As described above, the inclusion of lactose in the diet increased the ruminal butyrate concentration (Oba et al., 2015), and Górka et al. (2011) reported that sodium butyrate supplementation in calf starters tended to increase reticulorumen weight relative to whole stomach weight in calves. Furthermore, butyrate stimulated epithelial cell proliferation and regulated cell differentiation and apoptosis in the gut (Heerdt et al., 1994; Augenlicht et al., 1999), and increased ruminal butyrate enhanced GLP-2 secretion (Elsabagh et al., 2017). The hallmark of GLP-2 action is an increase in weights of the small intestine (Drucker et al., 1996; Hartmann et al., 2000) and large intestine (Lovshin et al., 2000) in nonruminants. In addition, Taylor-Edwards et al. (2011) reported that ruminants respond to GLP-2 in a manner similar to that of nonruminants. However, the GIT weights did not differ across the 3 treatments in the present study (Table 4), 
Table 4. Gastrointestinal tract weights for calves fed starters containing lactose at 0 (control), 5 (LAC5), or $10 \%$ (LAC10) on a DM basis

\begin{tabular}{lccccc}
\hline & \multicolumn{3}{c}{ Treatment } & & \\
\cline { 2 - 3 } Item & Control & LAC5 & LAC10 & SEM & $P$-value \\
\hline Weight, kg & & & & & \\
$\quad$ Reticulorumen & 2.67 & 2.30 & 2.53 & 0.10 & 0.06 \\
Omasum & 0.60 & 0.51 & 0.55 & 0.03 & 0.20 \\
Abomasum & 0.58 & 0.55 & 0.58 & 0.02 & 0.65 \\
Small intestine & 3.06 & 2.87 & 3.17 & 0.09 & 0.08 \\
Large intestine & 1.17 & 1.03 & 1.12 & 0.05 & 0.14 \\
\% of BW & & & & 0.2 & 0.10 \\
Reticulorumen & 2.2 & 2.0 & 2.0 & 0.03 & 0.34 \\
Omasum & 0.50 & 0.44 & 0.47 & 0.01 & 0.99 \\
Abomasum & 0.49 & 0.49 & 0.49 & 0.06 & 0.34 \\
Small intestine & 2.56 & 2.53 & 2.66 & 0.03 & 0.34 \\
Large intestine & 0.98 & 0.94 & 0.91 & & \\
\% of whole stomach & & & & 0.9 & 0.68 \\
Reticulorumen & 69.3 & 68.1 & 69.1 & 0.8 & 0.90 \\
Omasum & 15.5 & 15.1 & 15.1 & 0.5 & 0.08 \\
Abomasum & 15.2 & 15.7 & 15.6 & & \\
\hline
\end{tabular}

and the plasma GLP-2 concentration at 11 wk of age were not correlated with the weights of the small and large intestines $(\mathrm{r}=0.067, P=0.67$ and $\mathrm{r}=0.163, P=$ 0.30, respectively; data not shown). Górka et al. (2014) reported that sodium butyrate supplementation in milk replacers had a greater effect on small intestine development than sodium butyrate supplementation in calf starters. Herrick et al. (2017) reported that cows that were administered sodium butyrate into the rumen had higher rumen butyrate concentration than did cows administered lactose, and these results were observed following the administration of a dose that was intended to induce an increased ruminal butyrate concentration, similar to that observed following sodium butyrate administration into the rumen. Further, absolute GLP-2 concentration after weaning (8 to 11 wk of age) did not differ across 3 treatments. Therefore, lactose inclusion in calf starter up to $10 \%$ of DM might not affect the mass of GIT in calves. Górka et al. (2014) reported that sodium butyrate supplementation in calf starters increased crypt depth and tunica mucosa thickness in the duodenum, villus height in distal jejunum, and crypt depth in the ileum without changing the digestive organ mass significantly. However, unfortunately, we did not collect the epithelial tissue samples. Further study is warranted on evaluating the effect of lactose feeding on epithelial development as well as mass of GIT in calves.

Plasma GLP-2 concentration positively correlated with plasma insulin concentrations $(\mathrm{r}=0.60, P<0.01$; Table 3). To the best of our knowledge, the relationship between GLP-2 and insulin has not been reported. The positive correlation between GLP-2 and insulin might have resulted from the secondary order GLP-1 insulinotropic actions.

\section{CONCLUSIONS}

Lactose inclusion in calf starters may contribute to the maintenance of high plasma GLP-1 and GLP-2 concentrations via possible increase in ruminal butyrate production. Although the increase of both plasma GLP-1 and GLP-2 concentrations suggests that the gut peptides might be co-secreted, depending on the starter intake, GLP-1 and GLP-2 secretion might not always be parallel in calves under the conditions in this study. The GIT weights were not affected by the inclusion of lactose in calf starters, but further studies that evaluate the effects of lactose feeding on epithelial development as well as the weights of the GIT in calves are required. These results extend our understanding of the effect of lactose feeding on the secretion of gut peptides and may have implications for improvement of performance in calves.

\section{ACKNOWLEDGMENTS}

This work was supported by The National Federation of Dairy Co-operative Associations (ZEN-RAKUREN).

\section{REFERENCES}

Acitores, A., N. González, V. Sancho, L. Arnés, I. Valverde, W. J. Malaisse, and M. L. Villanueva-Peñacarrillo. 2005. Participation of protein kinases in the stimulant action of GLP-1 on 2-deoxy-Dglucose uptake by normal rat skeletal muscle. Horm. Metab. Res. $37: 275-280$. 
Augenlicht, L. H., G. M. Anthony, T. L. Church, W. Edelmann, R. Kucherlapati, K. Yang, M. Lipkin, and B. G. Heerdt. 1999 Short-chain fatty acid metabolism, apoptosis, and Apc-initiated tumorigenesis in the mouse gastrointestinal mucosa. Cancer Res. 59:6005-6009.

Burrin, D. G., B. Stoll, and X. Guan. 2003. Glucagon-like peptide 2 function in domestic animals. Domest. Anim. Endocrinol. 24:103122

Castro, J. J., S. Y. Morrison, A. Hosseinni, J. J. Loor, J. K. Dracley, and I. R. Ipharraguerre. 2016. Secretion of glucagon-like peptide-2 responds to nutrient intake but not glucose provision in milk-fed calves. J. Dairy Sci. 99:5793-5807.

Cordier-Bussat, M., C. Bernard, F. Levenez, N. Klages, B. Laser-Ritz, J. Philippe, J. A. Chayvialle, and J. C. Cuber. 1998. Peptones stimulate both the secretion of the incretin hormone glucagon-like peptide 1 and the transcription of the proglucagon gene. Diabetes 47:1038-1045

DeFrain, J. M., A. R. Hippen, K. F. Kalscheur, and D. J. Schingoethe. 2004. Feeding lactose increases ruminal butyrate and plasma $\beta$-hydroxybutyrate in lactating dairy cows. J. Dairy Sci. 87:2486-2494

Drucker, D. J., P. Erlich, S. L. Asa, and P. L. Brubaker. 1996. Induction of intestinal epithelial proliferation by glucagon-like peptide 2 . Proc. Natl. Acad. Sci. USA 93:7911-7916.

Edwards, C. M. B., A. V. Edwards, and S. R. Bloom. 1997. Cardiovascular and pancreatic endocrine responses to glucagon-like peptide-1 (7-36) amide in the conscious calf. Exp. Physiol. 82:709-716.

Elliott, R. M., L. N. Morgan, J. A. Tredger, S. Deacon, J. Wright, and V. Marks. 1993. Glucagon-like peptide-1 (7-36) amide and glucosedependent insulinotropic polypeptide secretion in response to nutrient ingestion in man: Acute post-prandial and 24-h secretion patterns. J. Endocrinol. 138:159-166.

Elsabagh, M., Y. Inabu, T. Sugino, and T. Obitsu. 2017. Response of plasma glucagon-like peptide-2 to feeding pattern and intraruminal administration of volatile fatty acids in sheep. Domest. Anim. Endocrinol. 60:31-41.

Faulkner, A. 1991. Sensitivity of serum insulin concentrations to glucagon-like peptide 1 (7-36) amide in sheep. Biochem. Soc. Trans. 19:311S.

Fukumori, R., T. Mita, T. Sugino, T. Obitsu, and K. Taniguchi. 2012. Plasma concentrations and effects of glucagon-like peptide-1 (736) amide in calves before and after weaning. Domest. Anim. Endocrinol. 43:299-306.

Gao, X., and M. Oba. 2016. Effect of increasing dietary nonfiber carbohydrate with starch, sucrose, or lactose on rumen fermentation and productivity of lactating dairy cows. J. Dairy Sci. 99:291-300.

Górka, P., Z. M. Kowalski, P. Pietrzak, A. Kotunia, W. Jagusiak, J. J. Holst, R. Guilloteau, and R. Zabielski. 2011. Effect of method of delivery of sodium butyrate on rumen development in newborn calves. J. Dairy Sci. 94:5578-5588.

Górka, P., Z. M. Kowalski, P. Pietrzak, A. Kotunia, R. Kiljanczyk, J. Flaga, J. J. Holst, P. Guilloteau, and R. Zabielski. 2009. Effect of sodium butyrate supplementation in milk replacer and starter diet on rumen development in calves. J. Physiol. Pharmacol. 60:47-53.

Górka, P., P. Pietrzak, A. Kotunia, R. Zabielski, and Z. M. Kowalski. 2014. Effect of method of delivery of sodium butyrate on maturation of the small intestine in newborn calves. J. Dairy Sci. 97:1026-1035

Hartmann, B., J. Thulesen, H. Kissow, S. Thulesen, C. Orskov, C. Ropke, S. S. Poulsen, and J. J. Holst. 2000. Dipeptidylpeptidase IV inhibition enhances the intestinotrophic effect of glucagon-like peptide 2 in rats and mice. Endocrinology 141:4013-4020.

Heerdt, B. G., M. A. Houston, and L. H. Augenlicht. 1994. Potentiation by specific short-chain fatty acids of differentiation and apoptosis in human colonic carcinoma cell lines. Cancer Res. 54:3288-3294.

Herrick, K. J., A. R. Hippen, K. F. Kalscheur, D. J. Schingoethe, D. P. Casper, S. C. Moreland, and J. E. van Eys. 2017. Singledose infusion of sodium butyrate, but not lactose, increases plasma $\beta$-hydroxybutyrate and insulin in lactating dairy cows. J. Dairy Sci. 100:757-768
Holst, J. J., J. Christiansen, and C. Kühl. 1976. The enteroglucagon response to intrajejunal infusion of glucose, triglycerides, and sodium chloride, and its relation to jejunal inhibition of gastric acid secretion in man. Scand. J. Gastroenterol. 11:297-304.

Holz, G. G. IV, W. M. Kühtreiber, and J. F. Habener. 1993. Pancreatic beta-cells are rendered glucose-competent by the insulinotropic hormone glucagon-like peptide-1(7-37). Nature 361:362-365.

Kato, Y., D. H. Yu, and M. Schwartz. 1999. Glucagon-like peptide 2 enhances small intestinal absorptive function and mucosal mass in vivo. J. Pediatr. Surg. 34:18-20.

Klotz, J. L., and R. N. Heitmann. 2006. Effect of weaning and ionophore supplementation on selected blood metabolites and growth in dairy calves. J. Dairy Sci. 89:3587-3598.

Klotz, J. L., and R. N. Heitmann. 2007. Changes in net portal nutrient flux to response to weaning transition and ionophore supplementation in dairy calves. J. Dairy Sci. 90:1326-1339.

Kurose, Y., S. Asakuma, T. Sugino, and Y. Terashima. 1999. Central and peripheral effects of glucagon-like peptide 1 (GLP-1) on food intake and plasma concentrations of glucose and insulin in the goats. South Afr. J. Anim. Sci. (Proc.) 29:14-15.

Lane, M. A., R. L. Baldwin, and B. W. Jesse. 2000. Sheep rumen metabolic development in response to age and dietary treatments. J. Anim. Sci. 78:1990-1996.

Lovshin, J., B. Yusta, I. Iliopoulos, A. Migirdicyan, L. Dableh, and P. L. Brubaker. 2000. Ontogeny of the glucagon-like peptide 2 receptor axis in the developing rat intestine. Endocrinology 141:41944201.

Luque, M. A., N. González, L. A. Márquez Acitores, A. Redondo, M. Morales, I. Valverde, and M. L. Villanueva-Peñacarrillo. 2002 Glucagon-like peptide- 1 (GLP-1) and glucose metabolism in human myocytes. J. Endocrinol. 173:465-473.

Nian, M., J. Gu, D. M. Irwin, and D. J. Drucker. 2002. Human glucagon gene promoter sequence regulation tissue-specific versus nutrient-regulated gene expression. Am. J. Physiol. Regul. Integr. Comp. Physiol. 282:R173-R183.

O'Halloran, D. J., G. C. Nikou, B. Kreymann, M. A. Ghatei, and S. R. Bloom. 1990. Glucagon like peptide-1 (7-36)-NH2: A physiological inhibitor of gastric acid secretion in man. J. Endocrinol. 126:169-173.

Oba, M., J. L. Mewis, and Z. Zhining. 2015. Effects of ruminal doses of sucrose, lactose, and corn starch on ruminal fermentation and expression of genes in ruminal epithelial cells. J. Dairy Sci. 98:586-594.

Reimer, R. A., and M. I. McBurney. 1996. Dietary fiber modulates intestinal proglucagon messenger ribonucleic acid and postprandial secretion of glucagon-like peptide 1 and insulin in rats. Endocrinology 137:3948-3956.

Reimer, R. A., A. B. Thomson, R. V. Rajotte, T. K. Basu, B. Ooraikul, and M. I. McBurney. 1997. A physiological level of rhubarb fiber increases proglucagon gene expression and modulates intestinal glucose up take in rats. J. Nutr. 127:1923-1928.

Relling, A. E., and C. K. Reynolds. 2008. Abomasal infusion of casein, starch and soybean oil differentially affect plasma concentrations of gut peptides and feed intake in lactating dairy cows. Domest. Anim. Endocrinol. 35:35-45.

Ritzel, U., A. Fromme, M. Ottleben, U. Leonhardt, and G. Ramadori. 1997. Release of glucagon-like peptide 1 (GLP-1) by carbohydrates in the perfused rat ileum. Acta Diabetol. 34:18-21.

Saegusa, A., K. Inouchi, M. Ueno, Y. Inabu, S. Koike, T. Sugino, and M. Oba. 2017. Effects of partial replacement of corn grain with lactose in calf starters on ruminal fermentation and growth performance. J. Dairy Sci. 100:6177-6186.

Sancho, V., M. V. Trigo, N. González, I. Valverde, W. J. Malaisse, and M. L. Villanueva-Peñacarrillo. 2005. Effects of glucagon-like peptide- 1 and exendins on kinase activity, glucose transport and lipid metabolism in adipocytes from normal and type-2 diabetic rats. J. Mol. Endocrinol. 35:27-38.

Sancho, V., M. V. Trigo, A. Martín-Duce, N. Gonzalez, A. Acitores, L. Arnés, I. Valverde, W. J. Malaisse, and M. L. Villanueva-Penacarrillo. 2006. Effect of GLP-1 on D-glucose transport, lipolysis 
and lipogenesis in adipocytes of obese subjects. Int. J. Mol. Med. 17:1133-1137.

Sander, E. G., R. G. Warner, H. N. Harrison, and J. K. Loosli. 1959. The stimulatory effect of sodium butyrate and sodium propionate on the development of rumen mucosa in the young calf. J. Dairy Sci. 42:1600-1605.

Shin, E. D., J. L. Estall, A. Izzo, D. J. Drucker, and P. L. Brubaker. 2005. Mucosal adaptation to enteral nutrients is dependent on the physiologic actions of glucagon-like peptide-2 in mice. Gastroenterology 128:1340-1353.

Steele, M. A., G. B. Penner, F. Chaucheyras-Durand, and L. L. Guan. 2016. Development and physiology of the rumen and the lower gut: Targets for improving gut health. J. Dairy Sci. 99:4955-4966.

Stobo, I. J., J. H. Roy, and H. J. Gaston. 1966. Rumen development in the calf. 1. The effect of diets containing different proportions of concentrates to hay on rumen development. Br. J. Nutr. 20:171188

Takahashi, H., Y. Kurose, S. Kobayashi, T. Sugino, M. Kojima, K. Kangawa, Y. Hasegawa, and Y. Terashima. 2006. Ghrelin enhances glucose-induced insulin secretion in scheduled meal-fed sheep. J. Endocrinol. 189:67-75.

Takahashi, H., H. Manaka, K. Suda, N. Fukase, M. Tominaga, H. Sasaki, K. Kawai, and S. Ohashi. 1990. Radioimmunoassay for glucagon-like peptide- 1 in plasma using N-terminal and C-terminal directed antibodies: A physiological insulinotropic role of GLP-1 (7-36) amide. Biomed. Res. 11:99-108.
Tappenden, K. A., and M. I. McBurney. 1998. Systemic short-chain fatty acids rapidly alter gastrointestinal structure, function, and expression of early response genes. Dig. Dis. Sci. 43:1526-1536.

Taylor-Edwards, C. C., D. G. Burrin, J. J. Holst, K. R. McLeod, and D. L. Harmon. 2011. Glucagon-like peptide-2 (GLP-2) increases small intestinal blood flow and mucosal growth in ruminating calves. J. Dairy Sci. 94:888-898.

Taylor-Edwards, C. C., D. G. Burrin, J. C. Matthews, K. R. McLeod, J. J. Holst, and D. L. Harmon. 2010. Expression of proglucagon and glucagon-like peptide-2 (GLP-2) receptor mRNA in the ruminant gastrointestinal tract and the influence of energy intake. Domest. Anim. Endocrinol. 39:181-193.

Unger, R. H., A. Ohneda, I. Valverde, A. M. Eisentraut, and J. Exton. 1968. Characterization of the response of circulating glucagon like immunoreactivity to intraduodenal and intravenous administration of glucose. J. Clin. Invest. 47:48-65.

Warner, R. G., W. P. Flatt, and J. K. Loosli. 1956. Ruminant nutrition, dietary factors influencing development of ruminant stomach. J. Agric. Food Chem. 4:788-792.

Zhou, J., M. Hegsted, K. L. McCutcheon, M. J. Keenan, X. Xi, A. M. Raggio, and R. J. Martin. 2006. Peptide YY and proglucagon mRNA expression patterns and regulation in the gut. Obesity (Silver Spring) 14:683-689. 